Abstract-We examined the age and growth of dusky grouper (Epinephelus marginatus) at offshore Carpinteiro Bank $\left(32^{\circ} 16^{\prime} \mathrm{S}\right.$; $52^{\circ} 47^{\prime} \mathrm{W}$ ) in the southwestern Atlantic through the analysis of growth increments in otoliths. We also examined the hypothesis that this offshore habitat represents a superior site for fish growth compared with inshore habitats. Samples consisted of 211 groupers captured by small-scale fisheries between 2008 and 2011 and with total lengths ranging from 150 to $1160 \mathrm{~mm}$. Otolith growth increments were deposited once per year, and opaque bands formed mostly during the summer, as determined through marginal increment analysis. Ages ranged from 1 to 40 years, and most fish were aged to be between 2 and 8 years (global mean: 7.4 years, standard deviation 6.9). Von Bertalanffy growth parameters for pooled sexes were $L_{\infty}=900.9$ $\mathrm{mm}, K=0.129$ and $t_{0}=-1.45$. Fish from the offshore habitat were generally older and their mean sizes were significantly larger at ages $3,4,5$, and 6 than those of fish from the inshore habitat. Our findings highlight the importance of Carpinteiro Bank as an important growth habitat for dusky groupers in the southwestern Atlantic and indicate that fishery management measures should be implemented to ensure the maintenance of this endangered species in this offshore bank in the future.

Manuscript submitted 18 June 2013. Manuscript accepted 22 August 2014. Fish. Bull. 112:311-321 (2014). doi:10.7755/FB.112.4.7

The views and opinions expressed or implied in this article are those of the author (or authors) and do not necessarily reflect the position of the National Marine Fisheries Service, NOAA.

\title{
Age and growth of dusky grouper (Epinephe/us marginatus) (Perciformes: Epinephelidae) in the southwestern Atlantic, with a size comparison of offshore and littoral habitats
}

\author{
Mario V. Condini (contact author) ${ }^{1}$ \\ Cristiano Q. Albuquerque ${ }^{2}$ \\ Alexandre M. Garcia ${ }^{1}$ \\ Email address for contact author: mvcondini@gmail.com \\ 1 Instituto de Oceanografia \\ Universidade Federal do Rio Grande \\ Avenida Itália km 8, Carreiros \\ 96201-900, Rio Grande \\ Rio Grande do Sul, Brazil \\ 2 Departamento de Oceanografia e Ecologia \\ Universidade Federal do Espírito Santo \\ 29075-900, Vitória \\ Espírito Santo, Brazil
}

The dusky grouper (Epinephelus marginatus) (Epinephelidae) inhabits shelter-rich, hard substrata on the continental shelf along the eastern coast of South America from Brazil to Argentina (Figueiredo and Menezes, 1980; Irigoyen et al., 2005), throughout the Mediterranean Sea, and from the British Isles around the southern tip of Africa (Heemstra and Randall, 1993) to southern Mozambique (Fennessy, 2006). Adults inhabit rocky bottoms, generally at depths up to 50 $\mathrm{m}$, and they can be found occasionally at depths up to $250 \mathrm{~m}$ (Bruslé, 1985; Heemstra and Randall, 1993), whereas juveniles are usually found in coastal tide pools (Azevedo et al., 1995). Like other epinephelids, the dusky grouper is a slow-growing protogynous hermaphrodite species with late sexual maturation and low natural mortality rates (Manooch and Mason, 1987), and it is also a highly valuable commercial fish (Heemstra and Randall, 1993). These combined characteristics make the dusky grouper highly vulnerable to overfishing. This species is classified as endangered by the International Union for Conservation of Nature (Cornish and
Harmelin-Vivien, 2004), with a decreasing global population trend.

The dusky grouper is the only large epinephelid that is usually found along the extreme southern part of the Brazilian coast, where it is fished over inshore rocky bottoms (depths $<5 \mathrm{~m}$ ) and offshore banks (depths $>10 \mathrm{~m}$ ) by small-scale fisheries (Condini et al., 2007). Offshore populations of dusky grouper occasionally are targeted opportunistically by large-scale commercial fisheries that use hand lines, but the species is otherwise not a commercially targeted species. The most frequently visited site in the southwestern Atlantic for commercial offshore fishing of this species is Carpinteiro Bank.

The role of dusky groupers in the coastal ecosystems of South America is not completely understood. Given the likely importance of this species as a predator (Reñones et al., 2002), it is imperative to understand the implications of any sort of commercial exploitation that may be involved. To prevent stock collapse, reef fishes should be fished carefully because slow-growing, late-maturing fish species are found frequently in coastal ecosystems and are vulner- 

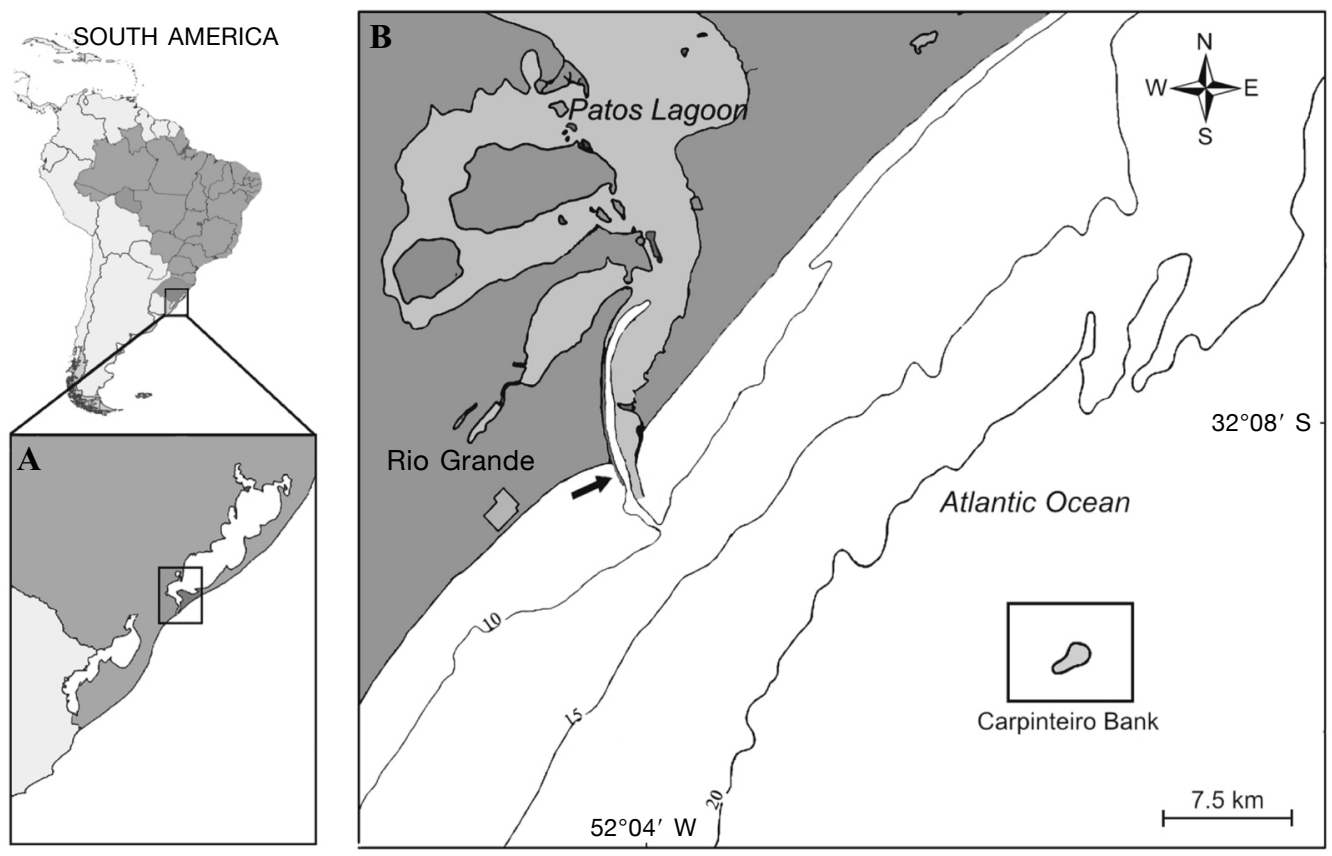

Figure 1

Map showing (A) Patos Lagoon and its estuarine zone $\left(10.36 \mathrm{~km}^{2}\right)$ in Rio Grande, the southernmost state in Brazil; (B) the location of the pair of rocky jetties at the mouth of the lagoon (arrow) and, in the adjacent marine area, Carpinteiro Bank in the southwestern Atlantic. The lines along the coast denote the 10-, 15- and 20-m isobaths. The specimens of the dusky grouper (Epinephelus marginatus) sampled in this study were caught at the Carpinteiro Bank by small-scale fisheries from 2008 to 2011.

able particularly to overfishing (Coleman et al., 2000; Sadovy et al., 2013). Quantifying the age and growth of dusky groupers is required, therefore, to support adequate conservation and management of this species at its southernmost region of occurrence.

Previous investigations have provided initial information on the age structure of the dusky grouper in South America and also revealed the absence of reproduction in a coastal population associated with littoral rocky jetties from extreme southern Brazil (Seyboth et al., 2011). Those authors adopted the classification developed by Craig and Hastings (2007) that placed the dusky grouper in Mycteroperca. For our study, we followed the most recent classification (Craig et al., 2011), in which the species was retained in Epinephelus, given the absence of conclusive studies to change the genus. Another study conducted in this region revealed that the dusky grouper reproduces at offshore Carpinteiro Bank (Condini et al., 2014).

In this study, we validated the timing of increment deposition in otoliths and examined the aging structure and growth parameters of dusky grouper in an offshore habitat (Carpinteiro Bank, at depths of 15$25 \mathrm{~m}$ ). Because we had access to the original data of Seyboth et al. (2011), we also aimed to test the hypothesis, previously reported by Seyboth et al. (2011), that offshore habitats (depths of 15-25 m) may constitute better habitats for growth and reproduction of dusky groupers than inshore habitats (depths $<5 \mathrm{~m}$ ).

\section{Material and methods}

\section{Sampling, fish processing, and study area}

Dusky grouper samples examined in this study $(n=211)$ were identified according to Heemstra and Randall (1993). They were collected twice a month from landings in small-scale fisheries in Rio Grande, a port city in southern Brazil (Fig. 1), from 2008 to 2011. Fish were caught with hand lines, and their origin was evaluated through interviews with owners of fishing boats. Only fish caught specifically at the Carpinteiro Bank were considered. In the laboratory, the total length (TL) in millimeters and weight (WT) in grams of each specimen were measured, and sex was identified by a macroscopic examination of the gonads following $\mathrm{Ma}-$ rino et al. (2001). Male and female gonadal differences are quite clear in macroscopic examination for this hermaphroditic grouper (Marino et al., 2001; Condini et al., 2014). The Carpinteiro Bank ( $\left.32^{\circ} 16 \mathrm{~S} ; 51^{\circ} 47 \mathrm{~W}\right)$ (Fig. 1) is a submersed reef, with depths ranging from 15 to $25 \mathrm{~m}$, formed by beach rocks and is superficially 
colonized by bryozoans, sponges, crustaceans, polychaetes, and coralline algae (Buchmann et al., 2001). Located approximately $30 \mathrm{~km}$ offshore from the city of Rio Grande ( $\left.32^{\circ} \mathrm{S}\right)$, this bank is likely the most austral region where the dusky grouper is commercially exploited.

\section{Otolith processing}

The sagittal otoliths were dissected from all samples and stored dry. The otoliths were then embedded in epoxy resin and sectioned through the core with an Isomet ${ }^{1}$ low speed saw (Buehler, Lake Bluff, IL) coupled to a diamond wafering blade to obtain sections $0.4-0.6 \mathrm{~mm}$ thick. These sections were glued to histological glass slides, polished with fine sandpaper (grits of 20008000), embedded in Entellan mounting medium (Merck KGaA, Darmstadt, Germany), covered with thin glass slides, and, finally, examined under a stereomicroscope coupled to a computerized imaging system. All sections were photographed under transmitted light so that translucent and opaque bands in the otoliths could be appear as white and dark bands in the digital photographs, respectively. Each otolith was read 3 times at intervals of one month by an experienced reader with no prior knowledge of either fish size or previous reading results. Only those otoliths with at least 2 corresponding increment numbers were used in our study.

The precision of otolith readings was evaluated through analysis of average percent error (APE; Campana, 2001) with the following equation:

$$
A P E=100 \% \times \frac{1}{R} \sum_{i=1}^{R} \frac{\left|x_{\mathrm{ij}}-x_{\mathrm{j}}\right|}{x_{\mathrm{j}}},
$$

where $x_{\mathrm{ij}}=$ the $i$ th age determination of the $j$ th fish; $x_{\mathrm{j}}=$ the mean age estimate of the $j$ th fish; and $R=$ the number of times that each fish is aged.

\section{Validation and growth}

The timing of otolith incremental deposition was estimated through marginal increment analysis (MIA) following Manickchand-Heileman and Phillip (2000), with the extra growth expressed as a proportion of the previous year's growth:

$$
M I A=\left(R_{\mathrm{t}}-R_{\mathrm{t}}-1\right) /\left(R_{\mathrm{t}}-1-R_{\mathrm{t}}-2\right),
$$

where $\quad R_{\mathrm{t}}=$ the distance measured from the core to the otolith's edge;

$R_{\mathrm{t}}-1=$ the distance between the core and the distal margin of the last opaque band; and

$R_{\mathrm{t}}-2=$ the distance between the core and the distal margin of the penultimate opaque band.

\footnotetext{
${ }^{1}$ Mention of trade names or commercial companies is for identification purposes only and does not imply endorsement by the National Marine Fisheries Service, NOAA.
}

Growth increment measurements were conducted with otolith images by using the free software ImageTool (University of Texas Health Science Center, San Antonio), which was calibrated with a micrometric scale glass. For MIA, 188 otoliths (from fish of sizes from 277 to $1160 \mathrm{~mm}$ TL) were used. During summer, autumn, winter, and spring, 91, 48, 10, and 39 otoliths, respectively, were obtained,. Marginal increment values were averaged over the summer (January-March), autumn (April-June), winter (July-September) and spring (October-December). These averages were compared by using the nonparametric Kruskal-Wallis and MannWhitney tests (Zar, 1999) because the data were not normally distributed.

To estimate average growth, the number of otolith increments was modeled against TL by fitting a von Bertalanffy (Eq. 3) curve and by using a nonlinear least squares method (Ricker, 1975).

$$
T L=L_{\infty}\left(1-e^{-K\left(t-t_{0}\right)}\right),
$$

where $\mathrm{TL}=$ the $\mathrm{TL}$ corresponding to age $I$;

$L_{\infty}=$ the mean theoretical maximum TL;

$t_{0}=$ the theoretical age at zero length; and

$K=$ the growth coefficient, the rate at which the curve approaches the asymptote.

These parameters were estimated both on the basis of all samples (male+female) and on the basis of females only. Growth parameters were not estimated for males because of their small sample size $(n=11)$.

\section{Sea-surface temperatures}

Data on sea-surface temperatures (SSTs) were analyzed from a 40-year time series measured in the region neighboring the Carpinteiro Bank (specifically, between $32-32^{\circ} 50^{\prime} \mathrm{S}$ and $50-52^{\circ} \mathrm{W}$ ) made available by the Coastal and Estuarine Oceanography Laboratory of Rio Grande Federal University. SST data were averaged by season. Data on subsurface temperature were not available for this site.

\section{Framework for habitat comparison}

The hypothesis that offshore habitats may provide better environmental conditions for growth of dusky groupers than inshore habitats was tested by comparing mean sizes between fish from both sites. Specifically, the mean sizes at ages $3,4,5,6$, and 7 of fish collected offshore at the Carpinteiro Bank (depths of 15-25 m) were compared with the mean sizes of fish collected from the inshore rocky jetties of Rio Grande (depths $<5$ m) from 2007 to 2009 that were previously reported by Seyboth et al. (2011). These age groups were selected on the basis of the simultaneous availability of 10 or more individuals per age group at both sites. Lengthat-age data of inshore dusky groupers (Seyboth et al., 2011) were made available by those authors. Otoliths in this study and in Seyboth et al. (2011) were read 


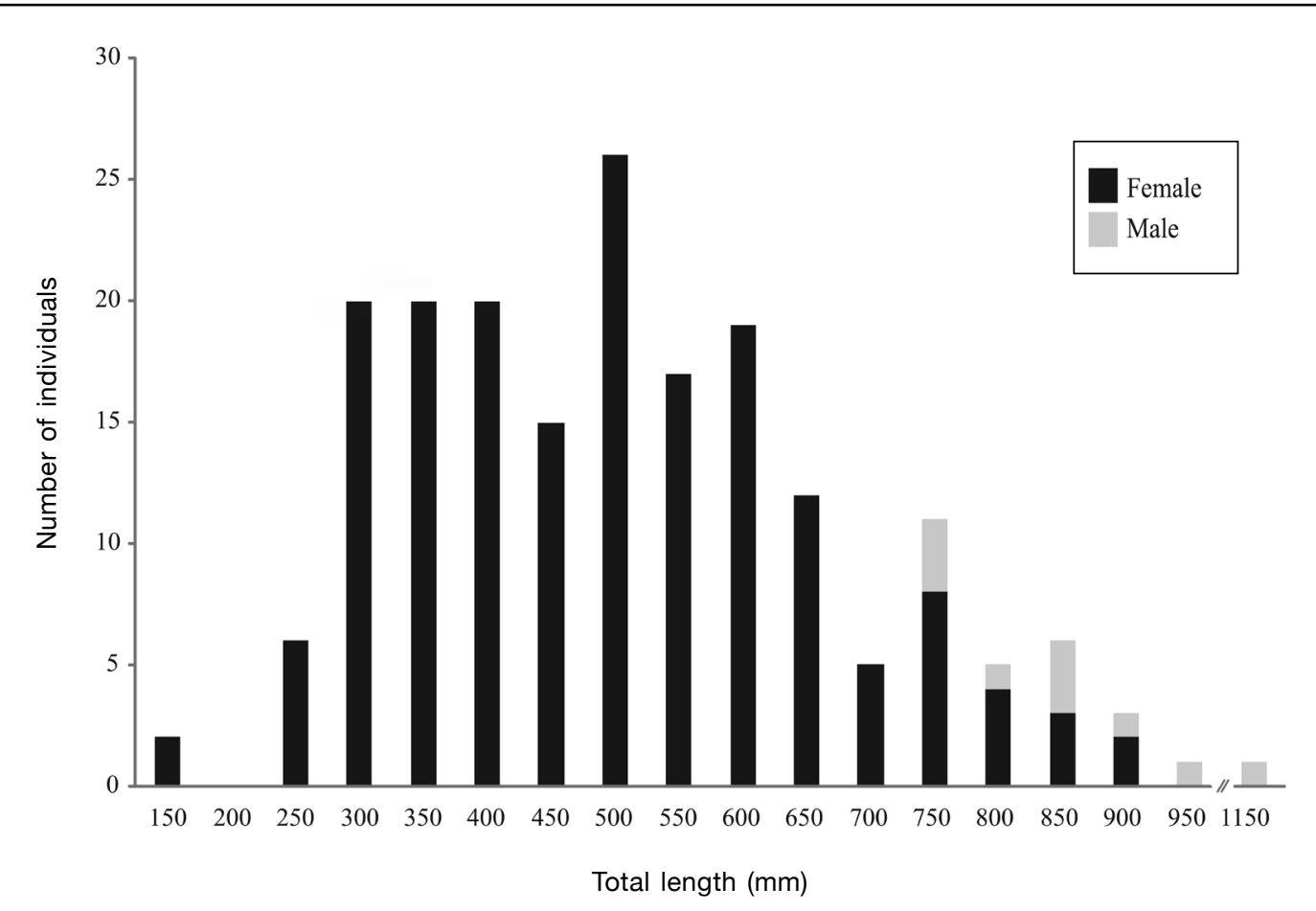

Figure 2

The total lengths, measured in millimeters, of female (black bars) and male (gray bars) dusky groupers (Epinephelus marginatus) caught at Carpinteiro Bank in the southwestern Atlantic ( $n=189)$ by small-scale fisheries from 2008 to 2011.

by the same person. Statistical analysis was conducted through a one-way analysis of variance after verification of the assumptions of normality and homoscedasticity (Zar, 1999).

\section{Results}

The TL of the dusky groupers sampled at Carpinteiro Bank ranged from 150 to $1160 \mathrm{~mm}$ TL (Fig. 2), and $80 \%$ of all samples measured between 300 and $700 \mathrm{~mm}$ TL. Females $(n=200)$ accounted for the vast majority of samples, whereas males $(n=11)$ composed only $5.5 \%$ of all samples. As expected, the mean TL for males (890.2 $\mathrm{mm}$ TL [standard deviation (SD) 122]) was larger than the mean for females $(512.1 \mathrm{~mm}$ TL [SD 152.9]). The length-weight relationship was $W T=0.00001 \times T L^{3.094}$ (coefficient of determination $\left[r^{2}\right]=0.985$ ), and the allometric coefficient was significantly different from 3 ( $t$-test: $P<0.0003)$, revealing that the species grows a little more in weight than in length.

The opaque and translucent growth bands in the otoliths of the dusky grouper were reasonably discernible, resulting in fine levels of precision during the process of otolith reading $(\mathrm{APE}=6.9 \%, n=211)$. Of the 211 examined otoliths, 22 were excluded from the analysis because of the absence of agreement among readings and 188 and 189 were used to validate the timing of deposition of growth increments and to estimate aging structure and growth, respectively.

The mean distribution of marginal increments in otoliths had significant differences among the fish collected during the 4 seasons (Kruskal-Wallis test: $P<0.03$; Fig. 3A). Marginal increment values were significantly lower during the winter than during the spring and summer (Mann-Whitney test: $P<0.005$ and $P<0.018$, respectively), and this pattern of differences was the same as the one observed for the proportion of opaque bands in the otolith edges (Fig. 3B). The same pattern was obtained for mean SST, where the proportion of opaque bands at the otolith edges was positively correlated with SST $\left(r^{2}=0.841\right)$.

Ages ranged from 1 to 40 years, and $85 \%$ of samples were aged between 2 and 8 years (Table 1 ). The mean ages for males and females were 26.7 years (SD 6.3) and 6.1 years (SD 4.9), respectively. The youngest sampled male was 20 years old and measured $760 \mathrm{~mm}$ TL, whereas no females were found at ages of more than 27 years or lengths greater than $933 \mathrm{~mm}$ TL. The von Bertalanffy parameters that were estimated for pooled sexes $\left(n=189 ; L_{\infty}=900.9 \mathrm{~mm}\right.$ TL $, K=0.129, t_{0}=-1.45$ years) showed smaller values for $L_{\infty}$ and larger values 


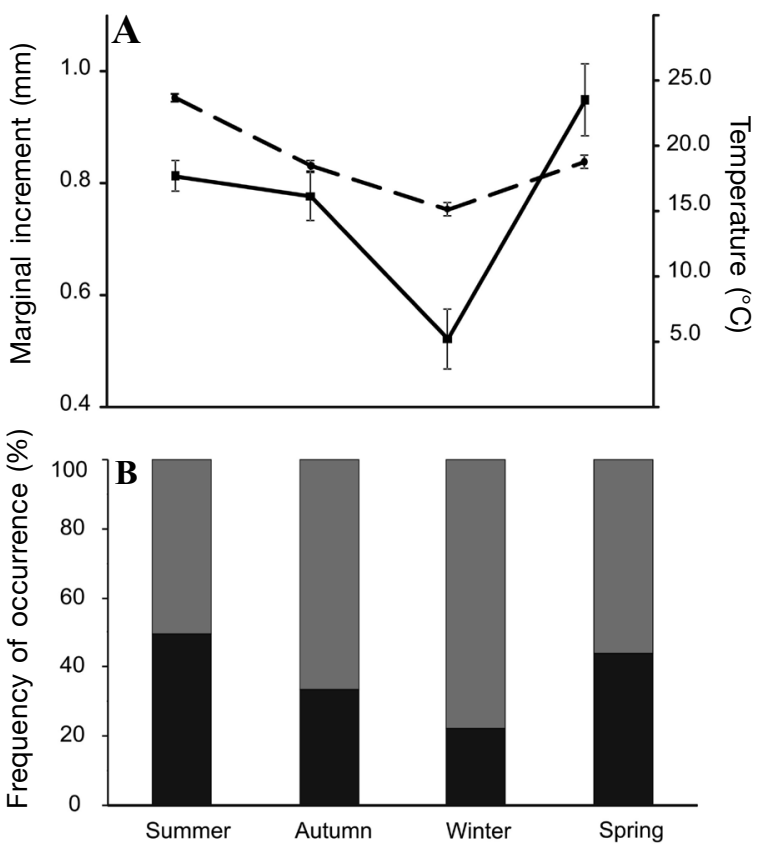

Figure 3

Seasonal variation $(\mathbf{A})$ in the mean marginal increment (solid lines) and sea-surface temperature (dashed line) and $(\mathbf{B})$ in the frequency of occurrence of opaque (black bars) and translucent edges (gray bars) of otoliths of dusky groupers (Epinephelus marginatus) caught at Carpinteiro Bank in the southwestern Atlantic by small-scale fisheries from 2008 to 2011 (summer: $n=91$; autumn: 48; winter: 10; and spring: 39 ). Error bars in panel A indicate \pm 1 standard error of the mean.

for $K$ when males $(n=11)$ were removed from the analy$\operatorname{sis}\left(n=178, L_{\infty}=851.1 \mathrm{~mm}\right.$ TL, $K=0.153, t_{0}=-1.06$ years $)$. The von Bertalanffy curve had the typical exponential asymptotic shape and allowed us to estimate that $70 \%$ of the asymptotic length of a fish was achieved at approximately 8 years of age (Fig. 4 ; Table 1 ).

A comparison of fish sizes at ages 3-6 between littoral sites and offshore sites showed that dusky groupers from the offshore Carpinteiro Bank were significantly larger than fish from the inshore rocky jetties located at the mouth of Patos Lagoon in the Rio Grande $(F=22.39, P<0.001$; Fig. 5), with mean differences of $11.7 \%, 19.6 \%, 16.7 \%$, and $11 \%$ per year, respectively. Significant differences, however, were not observed for age 7 .

\section{Discussion}

For otoliths to be used as reliable age indicators, they must display an internal structure of increments formed on a regular and predictable time scale. In dusky groupers, otoliths present well-defined growth increments that allow for age estimation at a relatively high precision. Translucent and opaque bands typically were formed during winter and summer, respectively, as determined through the analysis of marginal increments. Marginal increment analysis, however, is not considered the most trustworthy technique for validation of growth increments in otoliths (Campana, 2001), particularly where the temporal variation in environmental temperature is not strong enough to significantly influence fish metabolism. Therefore, to help increase confidence in validation, the seasonality of SST also was examined (Beckman and Wilson, 1995; Fablet et al., 2011). As expected, the results from marginal increment analysis closely followed the seasonal fluctuations in SST-a finding that supports the hypothesis that opaque and translucent increments in the otoliths of dusky groupers may be formed on an annual basis.

Moreover, the annual deposition of growth increments in otoliths has been reported previously for the dusky grouper (Fennessy, 2006; Reñones et al., 2007) and other grouper species, such as the yellowedge grouper (E. flavolimbatus [Manickchand-Heileman and Phillip, 2000]), yellowmouth grouper (Mycteroperca interstitialis [Manickchand-Heileman and Phillip, 2000]), leopard grouper (M. rosacea [Díaz-Uribe et al., 2001]), orange-spotted grouper (E. coioides [(Grandcourt et al., 2005)], and island grouper (M. fusca [Bustos et al., 2009]), indicating that it is an usual characteristic in epinephelids. The same pattern also was found for other long-lived fish species, such as the whitemouth croaker (Micropogonias furnieri [Haimovici and Umpierre, 1996]) and wreckfish (Polyprion americanus [Peres and Haimovici, 2004]), that inhabit the southwestern Atlantic.

The first finding on the growth of the dusky grouper in this study was the absence of males younger than 20 years or smaller than $760 \mathrm{~mm}$ TL-probably a result of protogynous hermaphroditism in this species (Heemstra and Randall, 1993; Andrade et al., 2003; Reñones et al., 2010; Condini et al., 2013). Under that reproductive strategy, dusky groupers are expected to first mature as females (at approximately 5 years old) and then change sex into males after approximately 7 years old (Reñones et al., 2010). Results from the few studies that have examined age and gonads simultaneously in dusky groupers indicate that males first appear in dusky grouper populations at diverse sizes and ages. For example, younger sampled males varied from 7 years (and $\sim 580 \mathrm{~mm}$ TL) in the Mediterranean Sea (Reñones et al., 2007) up to 9 years (and 810 mm TL) off southeast Africa (Fennessy, 2006). We recognize that variables like sampling selectivity, environmental conditions, intraspecific competition, and fishing pressure may be related to the age and size at which sexual transition occurs. However, at this point, we have no further evidence to explain the very low abundance of male dusky groupers found in our study. 


\section{Table 1}

Ages, number of specimens sampled (n), and means and ranges of total length (TL) and weight (WT) for dusky groupers (Epinephelus marginatus) caught at the Carpinteiro Bank in the southwestern Atlantic by small-scale fisheries from 2008 to 2011. Standard deviations of the means (SD) are provided in parentheses.

\begin{tabular}{|c|c|c|c|c|c|}
\hline Age (years) & $n$ & Mean TL (mm) & TL range (mm) & Mean WT (g) & WT range (g) \\
\hline 1 & 2 & $160.0(14.1)$ & $150-170$ & $58.2(14.6)$ & $47.9-68.5$ \\
\hline 2 & 27 & $325.7(38.0)$ & $290-405$ & $602.3(196.6)$ & $314.5-1227.9$ \\
\hline 3 & 28 & $385.9(38.0)$ & $277-453$ & $1081.2(297.6)$ & $400.0-1675.8$ \\
\hline 4 & 28 & $464.1(48.4)$ & $365-561$ & $1890.8(661.5)$ & $1015.0-3513.0$ \\
\hline 5 & 15 & $526.9(44.4)$ & $420-635$ & $2806.0(977.9)$ & $1284.0-5902.0$ \\
\hline 6 & 22 & $563.9(45.2)$ & $485-680$ & $3415.8(1053.9)$ & $2108.7-6530.0$ \\
\hline 7 & 21 & $587.3(60.6)$ & $475-671$ & $4135.1(1384.0)$ & $2103.3-7045.0$ \\
\hline 8 & 12 & $658.1(38.6)$ & $606-713$ & $5824.9(1553.5)$ & $4080.0-8950.0$ \\
\hline 9 & 1 & 532.0 & 532.0 & 3171.0 & 3171.0 \\
\hline 10 & 3 & $709.7(57.6)$ & $650-765$ & $7213.3(2725.1)$ & $4590.0-10030.0$ \\
\hline 11 & 2 & $744.0(50.9)$ & $708-780$ & $7137.5(88.4)$ & $7075.0-7200.0$ \\
\hline 14 & 3 & $748.3(72.9)$ & $665-800$ & $7785.8(2671.2)$ & $4725.8-9651.5$ \\
\hline 15 & 2 & $774.0(28.3)$ & $754-794$ & $9390.0(3620.4)$ & $6830.0-11,950.0$ \\
\hline 17 & 2 & $729.5(36.1)$ & $704-755$ & $6715.0(792.0)$ & $6155.0-7275.0$ \\
\hline 18 & 3 & $762.3(87.9)$ & $668-842$ & 7746.7 (3225.9) & $5100.0-11,340.0$ \\
\hline 19 & 1 & 764.0 & 764.0 & 7025.0 & 7025.0 \\
\hline 20 & 1 & 850.0 & 850.0 & $10,000.0$ & $10,000.0$ \\
\hline 21 & 1 & 770.0 & 770.0 & 8100.0 & 8100.0 \\
\hline 22 & 2 & $825.0(7.1)$ & $820-830$ & $10,900.3(423.8)$ & $10,600.6-11,200.0$ \\
\hline 23 & 5 & $808.0(118.3)$ & $660-985$ & $10309.0(4650.2)$ & $6030.0-17,850.0$ \\
\hline 24 & 2 & $881.0(12.7)$ & $872-890$ & $10657.5(2605.7)$ & $8815.0-12,500.0$ \\
\hline 25 & 1 & 933.0 & 933.0 & $15,100,0$ & $15,100.0$ \\
\hline 27 & 1 & 910.0 & 910.0 & $16,300.0$ & $16,300.0$ \\
\hline 28 & 1 & 864.0 & 864.0 & $11,100.0$ & $11,100.0$ \\
\hline 29 & 1 & 917.0 & 917.0 & $14,335.0$ & $14,335.0$ \\
\hline 31 & 1 & 875.0 & 875.0 & $10,560.0$ & $10,560.0$ \\
\hline 34 & 1 & 981.0 & 981.0 & $11,700.0$ & $11,700.0$ \\
\hline 40 & 1 & 1160.0 & 1160.0 & $25,000.0$ & $25,000.0$ \\
\hline
\end{tabular}

Examination of the von Bertalanffy parameters revealed that dusky groupers from Carpinteiro Bank grow slightly faster and attain slightly smaller theoretical maximum lengths than fish sampled from other areas in other studies. Although the von Bertalanffy model provided realistic estimates of growth parameters, $L_{\infty}(900 \mathrm{~mm}$ TL) was considerably smaller than the maximum length actually observed in this study (1160 mm TL) because fish older than 25 years were poorly represented. Given that the growth parameters were estimated by least squares fitting, the addition of more old individuals would most likely increase $L_{\infty}$ and decrease $K$ because of the intrinsic antagonism of these parameters, and the revised set of parameters would be closer to the values reported in Table 2 . Therefore, our results indicate that fitting a von Bertalanffy model to our actual data tends to slightly overestimate $K$ and underestimate $L_{\infty}$ compared with a more realistic sampling size. Also, it may be possible that $K$ estimated for the Mediterranean Sea (see Table 2) were higher than the values for other areas because of limited sampling.
Groupers are generally recognized as long-lived fishes capable of reaching maximum ages of more than 60 years (e.g., Reñones et al., 2007). The maximum longevity of dusky groupers in this study was approximately 40 years, which is the second-highest longevity among the values observed worldwide (see Table 2). Currently, the most important factor influencing fish longevity most likely is fishing activity because fishing is expected to preferentially remove large, old fish from natural populations (King, 1995). According to local traditional fishermen, fisheries over the Carpinteiro Bank are known to have occurred since the 1960s, and fishing effort has been rising ever since. Additionally, fishing effort and the number of fishing boats operating in the region have increased during the last 3 decades (Cowx et al., 1998), and those changes could have resulted in the decreased availability of the older age classes of dusky grouper that we observed in this study. Another interesting finding was that approximately $40 \%$ of the fish captured offshore were immature $\left(L_{50}=496 \mathrm{~mm}\right.$ TL, as estimated from Condini et al., 2014). Given the com- 




bined evidence of the low availability of old fish with the rising fishing effort over the last 3 decades and the large proportion of young adult individuals sampled here, it is reasonable to suggest that this offshore population may be undergoing overfishing. Unfortunately, there are no official fish landing records to allow an estimation of capture trends over time. These data would be necessary to objectively infer the population status of dusky grouper in southern Brazil.
The sampling conducted in the our study was restricted to Carpinteiro Bank, and that limit may cause concern because it is shallower $(15-25 \mathrm{~m})$ than the depths (up to $40-50 \mathrm{~m}$ ) where larger groupers usually live (Heemstra and Randall, 1993). It is, therefore, plausible to argue that ontogenetic migration, which is usual in epinephelids (Dahlgren and Eggleston, 2000), could be withdrawing large-size $(>90 \mathrm{~cm})$ fish from the examined population because of their emigration toward waters with depths of 40-50 m. However, we posit that this notion is not the case for two main reasons. First, the continental shelf at the extreme southern part of Brazil basically is formed by sand bottoms, where reefs and rocks are scarce (Calliari and Klein 1993). There are just a few rocky banks that may provide habitat for groupers, and they are found specifically between the 20- to $30-\mathrm{m}$ isobaths (Cardoso and Haimovici, 2011). Among these banks, Carpinteiro, Solidão, and Torres are the most visited by fishing boats (Cardoso and Haimovici, 2011). Second, reproduction has been observed for dusky grouper in Carpinteiro Bank (Condini et al., 2014), supporting the idea that the whole life cycle of the examined population occurs in this bank. Given these arguments, we believe that the relatively low abundance of older ( $>15$ years) individuals is an in-






\section{Table 2}

Study site, aging structure, range of total lengths (TLs), age range, number of specimens sampled ( $n$ ), and von Bertalanffy growth parameters of dusky groupers (Epinephelus marginatus) examined in this study and in previous investigations. Ageing structures used were scales (Sc), sectioned otolith (So), and whole otolith (Wo). Von Bertalanffy growth parameters included $L_{\infty}$, the mean theoretical maximum TL; $t_{0}$, the theoretical age at zero length; and $K$, the growth coefficient or the rate at which the curve approaches the asymptote.

\begin{tabular}{|c|c|c|c|c|c|c|c|c|}
\hline Reference & Study site & $\begin{array}{l}\text { Aging } \\
\text { structure }\end{array}$ & $\begin{array}{l}\text { TL range } \\
(\mathrm{mm})\end{array}$ & $\begin{array}{l}\text { Age range } \\
\text { (years) }\end{array}$ & $n$ & $\begin{array}{c}L_{\infty} \\
(\mathrm{mm})\end{array}$ & $\begin{array}{c}K \\
\left(\text { years }^{-1}\right)\end{array}$ & $\begin{array}{c}T_{0} \\
\text { (years) }\end{array}$ \\
\hline Rafail et al. $(1969)^{1}$ & $\begin{array}{l}\text { Mediterranean Sea } \\
\text {-Egypt }\end{array}$ & $\mathrm{Sc}$ & $166-475$ & $1-7$ & 251 & 800 & 0.112 & -1.08 \\
\hline Chauvet $(1988)^{2}$ & $\begin{array}{c}\text { Mediterranean Sea } \\
\text { - Tunisia }\end{array}$ & $\mathrm{Sc} / \mathrm{Wo}$ & $53-1180$ & $0-36$ & 270 & 1144 & 0.090 & -0.75 \\
\hline Kara and Derbal $(1995)^{3}$ & $\begin{array}{c}\text { Mediterranean Sea } \\
\text { —Algeria }\end{array}$ & $\mathrm{Sc}$ & $197-567$ & $1-7$ & 41 & 785 & 0.160 & -0.73 \\
\hline Bouchereau et al. $(1999)^{4}$ & $\begin{array}{c}\text { Mediterranean Sea } \\
\text {-France }\end{array}$ & Sc & $200-1200$ & $1-14$ & 22 & 1359 & 0.080 & -0.80 \\
\hline Fennessy $(2006)^{5}$ & $\begin{array}{l}\text { Southern Western Indian } \\
\text {-FranceSouth Africa }\end{array}$ & So & $95-1020$ & $1-16$ & 215 & 1249 & 0.090 & -1.43 \\
\hline Reñones et al. $(2007)^{6}$ & $\begin{array}{c}\text { Western Mediterranean } \\
\text { —Spain }\end{array}$ & So & $66-1056$ & $0-61$ & 358 & 955 & 0.087 & -1.12 \\
\hline Seyboth et al. $(2011)^{7}$ & $\begin{array}{c}\text { Southern Western Atlantic } \\
\text { - Brazil }\end{array}$ & So & $260-800$ & $2-12$ & 108 & 1249 & 0.069 & -1.49 \\
\hline Present study & $\begin{array}{c}\text { Southern Western Atlantic } \\
\text { — Brazil }\end{array}$ & So & $150-1160$ & $1-40$ & 190 & 900 & 0.129 & -1.45 \\
\hline
\end{tabular}

1 Rafail S. Z., W. L. Daoud, and M. M. Hilal. 1969. Long line Mediterranean fisheries studies west of Alexandria. GFCM Stud. Rev. $42,16 \mathrm{p}$.

2 Chauvet, C. 1988. Étude de la croissance du mérou Epinephelus guaza (Linné, 1758) des côtes tunisiennes. Aquat. Living Resour. 1:277-288.

3 Kara M. H., and F. Derbal. 1995. Morphométrie, croissance et mortalité du Merou Epinephelus marginatus (Serranidae) des côtes de l'est algérien. Cah. Biol. Mar. 36:229-237.

4 Bouchereau J. L., P. Body, and C. Chauvet. 1999. Growth of the dusky grouper Epinephelus marginatus (Linnaeus, 1758) (Teleostei, Serranidae), in the natural marine reserve of Lavezzi Islands, Corsica, France. Sci. Mar. 63:71-77.

5 See Fennessy, 2006. (In literature cited section.)

6 See Reñones et al., 2007.

7 See Seyboth et al., 2011.

trinsic feature of the studied population rather than a sampling effect related to emigration toward deeper offshore habitats.

Dusky groupers from Carpinteiro Bank were older (mean age $=7.4$ years maximum observed age $=40$ years $)$ than fish from the inshore rocky jetties located in the mouth of Patos Lagoon in Rio Grande (mean age $=5.0$ years; maximum observed age $=12$ years; Seyboth et al., 2011). Our study provides compelling evidence that younger ( $<7$ years) dusky groupers from Carpinteiro Bank are also significantly larger than similar-age fish from the rocky jetties. Specifically, the sizes of offshore groupers at ages 3-6 are 11-19\% larger than inshore dusky groupers-a finding that leads to the hypothesis that environmental quality at the deeper offshore habitat may be better than that at the shallow inshore habitats.

In this study, we assume that differences on mean size-at-age between fish from the inshore and offshore habitats may be associated with differences in en- vironmental quality between both sites, and several types of evidence support this hypothesis. For example, freshwater runoff from the Patos Lagoon estuary is, perhaps, the most important physical factor that influences the studied population, particularly during El Niño events, when freshwater discharge into the lagoon increases and pushes the estuarine plume over the inshore zone (Garcia et al., 2003), decreasing salinity and disturbing fish communities (Garcia et al., 2003; Garcia et al., 2004). The large variations in salinity periodically experienced by the inshore population may cause osmotic stress, increasing the energy outlay required to maintain fish homeostasis (Schmidt-Nielsen, 2002). In contrast, the salinity variation at the offshore bank usually ranges from 26.8 to $36.6\left(\mathrm{Moller}^{2}\right.$ ), a level that is roughly a third of the salinity variability measured

\footnotetext{
2 Moller, O. 2012. Unpubl. data. Laboratório de Oceanografia Costeira e Estuarina, Institute de Oceanografia, Universidade Federal de Rio Grande, CP. 474, 96200-900, Brazil.
} 
at the inshore habitat (10.6 and 35.1 during winter and summer, respectively) (A. Garcia, unpubl. data). In fact, faster growth was reported in dusky groupers reared under a salinity of 35 compared with dusky groupers reared under mixohaline treatments with salinities of 20 and 27 (Gracia-López and Castelló-Orvay, 2003), indicating that less energy may be expended for body homeostasis in more salinity-stable marine waters than in more salinity-variable estuarine conditions. This evidence supports the hypothesis that salinity regimes may play a significant role in controlling the differential growth rates of dusky groupers observed in inshore and offshore habitats.

An additional environmental factor capable of influencing fish growth in our system is food availability. The diet of groupers from the rocky jetties of Rio Grande consisted mostly of small crabs (Condini et al., 2011), whereas groupers from the Carpinteiro Bank were found to feed mostly on fish (Condini, in press). Given that fish are known to be a higher-energy food resource than crustaceans (Reñones et al., 2002), food quality also may partially explain the faster growth observed in dusky groupers sampled at the Carpinteiro Bank.

\section{Conclusions}

Accurate age and growth parameters of fish populations are important for the efficiency of environmental protection actions. In this study, we have shown that dusky groupers from their southernmost population present growth performance similar to that observed worldwide, with maximum size and age of about 900 $\mathrm{mm}$ TL and 40 years, respectively. We have also shown that younger individuals with ages between 3 and 6 years sampled offshore (depths of 15-25 m) are larger on average than fish of the same age sampled inshore (depths $<5 \mathrm{~m}$ ). These findings indicate that offshore banks may provide higher quality habitats for dusky groupers than do inshore rocky habitats. Therefore, the dusky grouper population that inhabits this offshore bank should be a preferable target for fishery management actions (e.g., catch monitoring and fishing quotas) to prevent increases in the level of overfishing of this endangered species at its southernmost distribution limit in southwestern Atlantic.

\section{Acknowledgments}

We thank B. Ferreira, L. Romano, and G. Velasco for their comments on this manuscript, J. Castello for helping with infrastructure to process samples, L. Madureira for providing the 3-D bathymetric map of Carpinteiro Bank, and Osmas Moller for providing salinity data for the offshore site. M. Condini and A. Garcia acknowledge fellowship support from Conselho Nacional de Desenvolvimento Científico e Tecnológico
(CNPq; 140570/2013-6 and 305888/2012-9, respectively). C. Albuquerque is currently a postdoctoral fellow (CAPES-PNPD 02907/09-7). This study received financial support from the Fundação O Boticário de Proteção à Natureza (0753-20072).

\section{Literature cited}

Andrade, Á. B., L. F. Machado, M. Hostim-Silva, and J. P. Barreiros.

2003. Reproductive biology of the dusky grouper Epinephelus marginatus (Lowe, 1834). Braz. Arch. Biol. Technol. 46:373-382.

Azevedo, J. M. N., J. B. Rodríguez, M. Mendizabal, and L. M. Arruda.

1995. Study of a sample of dusky groupers, Epinephelus marginatus (Lowe, 1834), caught in the tide pool at Lajes do Pico, Azores. Bol. Mus. Mun. Funchal 4:55-64.

Beckman, D. W., and C. A. Wilson.

1995. Seasonal timing of opaque zone formation in fish otoliths. In Recent developments in fish otolith research (D. H. Secor, J. M. Dean, and S. E. Campana, eds.), p. 27-43. Univ. South Carolina Press, Columbia, SC.

Bruslé, J.

1985. Expose synoptique des données biologiques sur les mérous Epinephelus aeneus (Geoffroy Saint Hilaire, 1809) et Epinephelus guaza (Linnaeus, 1758) de l'Océan Atlantique et de le Méditerranée. FAO Fish. Synop. 129, 64 p. FAO, Rome.

Buchmann, F. S., M. Seeliger, L. Zanella, L. S. P. Madureira, L.

J. Tomazelli, and L. J.Calliari.

2001. Análise batimétrica e sedimentológica no estudo do Parcel do Carpinteiro, uma paleolinha de praia pleistocênica na antepraia do Rio Grande do Sul, Brasil. Pesquisas. 28:109-115.

Bustos, R., Á. Luque, and J. G. Pajuelo.

2009. Age estimation and growth pattern of the island grouper, Mycteroperca fusca (Serranidae) in an island population on the northwest coast of Africa. Sci. Mar. 73:319-328.

Calliari, L. J., and A. H. F. Klein.

1993. Características morfodinâmicas e sedimentológicas das praias oceânicas entre Rio Grande e Chuí, RS. Pesquisas 20:48-56.

Campana, S. E.

2001. Accuracy, precision and quality control in age determination, including a review of the use and abuse of age validation methods. J. Fish Biol. 59:197-242.

Cardoso, L. G., and M. Haimovici.

2011. Caracterização tecnológica, social, econômica e ecológica da atividade pesqueira sediada em Passo de Torres, Santa Catarina, Brasil. Bol. Inst. Pesca São Paulo 37:275-288.

Coleman, F. C., C. C. Koenig, G. R. Huntsman, J. A. Musick, A. M. Eklund, J. C. McGovern, R. W. Chapman, G. R. Sedberry, and C. B. Grimes.

2000. Long-lived reef fishes: the grouper-snapper complex. Fisheries 25(3):14-20.

Condini, M. V., A. M. Garcia, and J. P. Vieira.

2007. Descrição da pesca e perfil sócio-econômico do pescador da garoupa-verdadeira Epinephelus marginatus 
(Lowe) (Serranidae: Epinephelinae) no Molhe Oeste da Barra de Rio Grande, Rio Grande do Sul, Brasil. PanamJAS 2:279-287.

Condini, M. V., E. Seyboth, J. P. Vieira, and A. M. Garcia. 2011. Diet and feeding strategy of the dusky grouper Mycteroperca marginata (Actinopterygii: Epinephelidae) in a man-made rocky habitat in southern Brazil. Neotrop. Ichthyol. 9:161-168.

Condini, M. V., E. Seyboth, J. P. Vieira, A. S. Varela Jr., J. P. Barreiros, L. F. Fávaro, and A. M. Garcia.

2013. First record of the dusky grouper Epinephelus marginatus (Actinopterygii: Epinephelidae) undergoing sexual transition in the South Western Atlantic, Brazil. Hidrobiológica 23:448-451.

Condini, M. V., L. F. Fávaro, A. S. Varela Jr., and A. M. Garcia. 2014. Reproductive biology of the dusky grouper (Epinephelus marginatus) at the southern limit of its distribution in the south-western Atlantic. Mar. Freshw. Res. 65(2):142-152.

Condini, M. V., D. J. Hoeinghaus, and A. M. Garcia.

In press. Trophic ecology of dusky grouper Epinephelus Marginatus (Actinopterygii, Epinephelidae) in littoral and neritic habitats of southern Brazil as elucidated by stomach contents and stable isotope analyses. Hydrobiologia. doi:10.1007/s10750-014-2016-0

Cornish, A., and M. Harmelin-Vivien. (Grouper and Wrasse Specialist Group).

2004. Epinephelus marginatus. In IUCN 2012. IUCN red list of threatened species, vers. 2012.1. [Available from www.iucnredlist.org, accessed March 2012.]

Cowx, I. G., K. T. O'Grady, and M. Haimovici.

1998. Present state and perspectives for the southern Brazil shelf demersal fisheries. Fish. Manage. Ecol. 5:277-289.

Craig, M. T., and P. A. Hastings.

2007. A molecular phylogeny of the groupers of the subfamily Epinephelinae (Serranidae) with a revised classification of the Epinephelini. Ichthyol. Res. 54:1-17.

Craig, M. T., Sadovy de Mitcheson, Y. J., and P. C. Heemstra. 2011. Groupers of the world: a field and market guide, 424 p. CRC Press, Boca Raton, FL.

Dahlgren, C. P., and D. B. Eggleston.

2000. Ecological processes underlying ontogenetic habitat shifts in a coral reef fish. Ecology 81:22272240 .

Díaz-Uribe, J. G., J. F. Elorduy-Garay, and M. T. González-Valdovinos.

2001. Age and growth of the leopard grouper, Mycteroperca rosacea, in the southern Gulf of California, México. Pac. Sci. 55:171-182.

Fablet, R., L. Pecquerie, H. de Pontual, H. Høie, R. Millner, H.

Mosegaard, and S. A. L. M. Kooijman.

2011. Shedding light on fish otolith biomineralization using a bioenergetic approach. PLoS ONE 6(11): e27055. doi:10.1371/journal.pone.0027055

Fennessy, S. T.

2006. Reproductive biology and growth of the yellowbelly rockcod Epinephelus marginatus (Serranidae) from South-East Africa. Afr. J. Mar. Sci. 28:1-11.

Figueiredo, J. L., and N. A. Menezes.

1980. Manual de peixes marinhos do sudeste do Brasil. III. Teleostei (2), 90 p. Museu de Zoologia, Univ. São Paulo, São Paulo.
Garcia, A. M., J. P. Vieira, and K. O. Winemiller. 2003. Effects of 1997-1998 El Niño on the dynamics of the shallow-water fish assemblage of the Patos Lagoon estuary (Brazil). Estuar. Coast. Shelf Sci. 57:489-500.

Garcia, A. M., J. P. Vieira, K. O. Winemiller, and A. M. Grimm. 2004. Comparison of the 1982-1983 and 1997-1998 El Niño effects on the shallow-water fish assemblage of the Patos Lagoon estuary (Brazil). Estuaries 27:905-914.

Gracia López, V., and F. Castelló-Orvay.

2003. Preliminary data on the culture of juveniles of the dusky grouper, Epinephelus marginatus (Lowe, 1834). Hidrobiológica 13:321-327.

Grandcourt, E. M., T. Z. Al Abdessalaam, F. Francis, and A. L. Shamsi.

2005. Population biology and assessment of the orangespotted grouper, Epinephelus coioides (Hamilton, 1822), in the southern Arabian Gulf. Fish. Res. 74:55-68.

Haimovici, M., and R. G. Umpierre.

1996. Variaciones estacionales en la estructura poblacional del efectivo pesquero de corvina blanca Micropogonias furnieri (Desmarest, 1823) en el extremo sur del Brasil. Atlântica 18:179-203.

Heemstra, C. P., and J. E. Randall.

1993. FAO Species catalogue, vol. 16. Groupers of the world (Family Serranidae, Subfamily Epinephelinae): an annotated and illustrated catalogue of the grouper, rockcod, hind, coral grouper and lyretail species known to date. FAO Fish. Synop. 125, 382 p. FAO, Rome.

Irigoyen, A. J., D. E. Galván, and L. A. Venerus.

2005. Occurrence of dusky grouper Epinephelus marginatus (Lowe, 1834) in gulfs of northern Patagonia, Argentina. J. Fish Biol. 67:1741-1745.

King, M.

1995. Fisheries biology, assessment and management, 341 p. Fishing News Books, Blackwell Science, Oxford, UK.

Manickchand-Heileman, S. C., and D. A. T. Phillip.

2000. Age and growth of the yellowedge grouper, Epinephelus flavolimbatus, and the yellowmouth grouper, Mycteroperca interstitialis, off Trinidad and Tobago. Fish. Bull. 98:290-298.

Manooch, C. S., III, and D. L. Mason.

1987. Age and growth of the warsaw grouper and black grouper from the southeast region of the United States. Northeast Gulf Sci. 9:65-75.

Marino, G., E. Azzurro, A. Massari, M. G. Finoia, and A. Mandich.

2001. Reproduction in the dusky grouper from the southern Mediterranean. J. Fish Biol. 58:909-927.

Peres, M. B., and M. Haimovici.

2004. Age and growth of southwestern Atlantic wreckfish Polyprion americanus. Fish. Res. 66:157-169.

Reñones, O., N. V. C. Polunin, and R. Goni.

2002. Size related dietary shifts of Epinephelus marginatus in a western Mediterranean littoral ecosystem: an isotope and stomach content analysis. J. Fish Biol. 61:122-137.

Reñones, O., C. Piñeiro, X. Mas, and R. Goñi.

2007. Age and growth of the dusky grouper Epinephelus marginatus (Lowe 1834) in an exploited population of the western Mediterranean Sea. J. Fish Biol. 71:346-362.

Reñones, O., A. Grau, X. Mas, F. Riera, and F. Saborido-Rey. 2010. Reproductive pattern of an exploited dusky grouper Epinephelus marginatus (Lowe 1834) (Pisces: Serra- 
nidae) population in the western Mediterranean. Sci. Mar. 74:523-537.

Ricker, W. E.

1975. Computation and interpretation of biological statistics of fish populations. Bull. Fish. Res. Board Can. $191,382 \mathrm{p}$.

Sadovy, Y. M., M. T. Craig, A. A. Bertoncini, K. E. Carpenter, W. W. L. Cheung, J. H. Choat, A. S. Cornish, S. T. Fennessy, B. P. Ferreira, P. C. Heemstra, M. Liu, R. F. Myers, D. A. Pollard, K. L. Rhodes, L. A Rocha, B. C. Russell, M. A Samoilys, and J. Sanciangco.

2013. Fishing groupers towards extinction: a global assessment of threats and extinction risks in a billion dollar fishery. Fish Fish. 14:119-136.
Schmidt-Nielsen, K.

2002. Fisiologia animal-Adaptação e meio ambiente, 5th ed., 611 p. Livraria Editora Santos, Cambridge Univ. Press, São Paulo, Brazil.

Seyboth, E., M. V. Condini, C. Q. Albuquerque, A. S. Varela Jr., G. Velasco, J. P. Vieira, and A M. Garcia.

2011. Age, growth, and reproductive aspects of the dusky grouper Mycteroperca marginata (Actinopterygii: Epinephelidae) in a man-made rocky habitat in southern Brazil. Neotrop. Ichthyol. 9:849-856.

Zar, J. H.

1999. Biostatistical analysis, $4^{\text {th }}$ ed., 662 p. Prentice Hall, Upper Saddle River, NJ. 